\section{Diversity by episodic growth}

Québec's commitment to higher education is most apparent in the crowds of students that throng every academic building; they look full, and they are. Québec's population of university students amounts to 250,000 in round numbers, of whom 85 per cent are enroled in regular degree programmes. That implies a rate of participation in higher education of roughly 40 per cent of Québec's young people - not high for Canada, but creditable by most other standards.

But French-speaking Québec's great embarrassment is that at McGill, the most distinguished of its universities, the language of instruction is still English. Indeed, McGill is the chief source of highlevel skill, responsible for roughly a third of the 600 or so who graduate with PhDs in Québec each year. Moreover, McGill remains a dominant source of physicians and of medical research, despite the emergence of Toronto (the provincial capital of Ontario) as a second string to Canada's bow.

The present array of university institutions in Québec is in itself a guide to the history of separatism. McGill University was founded in 1821 almost by accident, when the will of a fur-trader of that name made the founding of a college a condition of a legacy of land and cash; it now has 30,000 students. Next came Bishop's University, an Anglican foundation (in 1843) sited near Sherbrooke, which remains largely a liberal arts college with 2,500 students. Laval University, half an hour's drive west of Montréal, is by contrast a Catholic Foundation (chartered as a university in 1853) whose roots lie in the seventeenth century and the seminary founded by the first Bishop of Montréal after the French occupation of Québec.

The University of Montréal is an out-

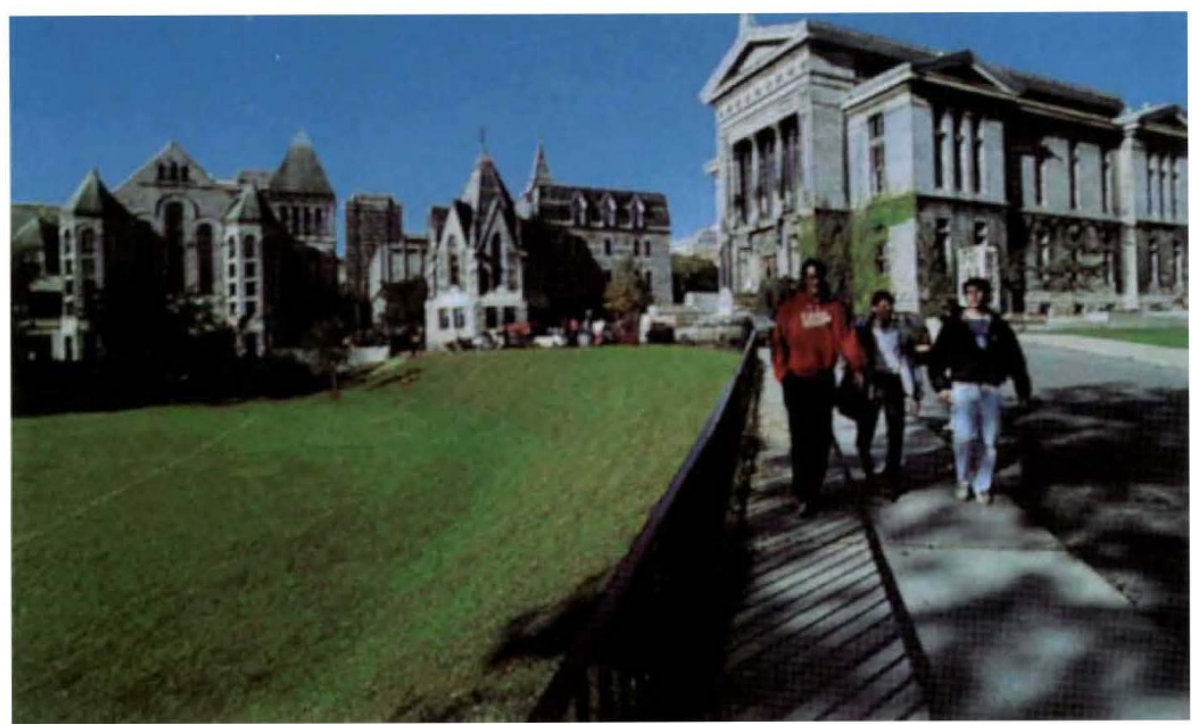

McGill University - dominant but less French than some versities graduate more than 5,000 people a year at this level, although only a quarter or so of them are qualified in science or engineering.

The university system is importantly stiffened by the way in which research institutes and centres have been scattered through it. These range from the way in which the once independent engineering school, the Ecole Polytechnique, has absorbed into the University of Montréal, to the Macromolecular Science and Engineering Research Centre at Laval (with an 80 -strong staff and more than 40 graduate students) and the Cognitive Research Centre at McGill two-thirds as big).

One chip on Québec's shoulder is that the federal government has been less generous towards Québec than to Ontario in the siting of federal research establishments. Although the two states are roughly equal in population (at roughly a quarter of the total for Canada), Québec has less than an eighth of federal reseach employees within its boundaries. But the federal Biotechnology Research Centre is conspicuously located in Québec.

Even so, the result of all this is that Québec's research community is quite substantial. The government reckons that there are 15,000 people working in industrial research and development and perhaps 10,000 (including professorial staff) engaged on research at the universities. In short, the numbers are great enough for the research community to regard itself as a substantial influence within the broader body politic, as well as an instrument for safeguarding its own future.

What should that be? Québec's university system has inevitably grown haphazardly, and has consequently a vast in-built diversity. There is good reason to believe that this meets the needs of the young people of the province, but the newer institutions need time in which to become maturely confident in teaching and research. And there is one respect in which the pressures of Francophonie are a handicap at this stage; Québec's universities are likely, because of the mere existence of the separation problem, to be denied the benefits of cosmopolitanism that healthy university systems need. Should Québec seek to avoid this risk by recruiting a steady trickle of academics from other French-speaking countries?

The size of the system also matters. Given people's specialization, it is inevitable that their academic colleagues and competitors will usually be outside Québec. Come separation or not, people expect that these links will persist.

The role of McGill in a separate Québec is something else again. The entering student body is split roughly 2 to 1 between those with English and French as their mother tongues, but the Frenchspeaking proportion is declining slowly. $\square$ 